\title{
MEMES, FAKE NEWS E PÓS-VERDADE OU COMO A TEORIA DE GÊNERO VIRA UMA "IDEOLOGIA PERIGOSA"
}

\author{
Luiz Augusto Mugnai VIEIRA JUNIOR* \\ Larissa PELÚCIO*
}

RESUMO: O presente artigo é baseado na tese nomeada "Quantas curtidas merece essa trans?" A recepção da transexualidade nas mídias digitais, realizada durante os anos de 2015 a 2018, a partir de imersão on-line oculta no Portal jornalístico Globo.com e em dois grupos do Facebook voltados para as temáticas de gênero. $O$ trabalho imersivo revelou intensas disputas e opiniões inflamadas em torno das questões de gênero. $\mathrm{O}$ meme da ideologia de gênero foi um dado que chamou atenção na pesquisa, tais como o negacionismo e a pós-verdade material que tocava, sobretudo, em questões morais, ironizando e/ou rechaçando mudanças de comportamentos atribuídas a políticas de governo, corruptoras da moral e que fomentariam inversão de valores. Os memes foram usados como uma espécie de arma de guerra contra as teorias de gênero, convertidas em "ideologia perigosa". Para a análise dos achados de pesquisa nos valemos das ferramentas teóricas dos estudos de gênero em sua vertente pós-estruturalista, dos estudos queer, flertando, ainda com aportes das ciências políticas.

PALAVRAS-CHAVE: Teoria de gênero. Ideologia de gênero. Memes. Pós-verdade. Negacionismo.

\footnotetext{
UNIPAR - Universidade Paranaense. Cascavel - PR - Brasil. 85810-240 - gutomugnai@prof.unipar.br. https://orcid.org/0000-0002-8525-0230.

" UNESP - Universidade Estadual Paulista "Júlio de Mesquita Filho". Faculdade de Arquitetura, Artes e Comunicação - Campus de Bauru. Departamento de Ciências Humanas. Faculdade de Filosofia e Ciências - Câmpus de Marília. Programa de Pós-Graduação em Ciências Sociais. Bauru - SP - Brasil. 17033-360 -larissa.pelucio@unesp.br. https://orcid.org/0000-0001-6212-3629.
} 


\section{Introdução}

As mídias contemporâneas são emocionais por excelência. Afetamos e nos deixamos afetar por esses meios. Curtimos; damos likes; manifestamos rancores; verbalizamos posições políticas; protestamos; articulamos ações; propagamos pontos de vistas; nos apaixonamos, conectamos intensamente o pessoal e o político (PELÚCIO, 2017, p.28).

O presente artigo é baseado na tese nomeada "Quantas curtidas merece essa trans?" A recepção da transexualidade nas mídias digitais desenvolvida por Luiz Augusto Mugnai Vieira Junior (2018), sob orientação de Larissa Pelúcio. Tal pesquisa, realizada durante os anos de 2015 a 2018, dedicou-se à compilação e reflexão sobre a recepção de matérias sobre transexualidade nas mídias digitais. Tanto a autora como o autor deste trabalho veem que esse cenário contemporâneo "crescentemente mediado por tecnologias digitais é tão real quanto o mundo não digital sempre foi" (PELÚCIO, 2017, p.54). Assim, a fim de acessar a visão de pessoas comuns, quer dizer não especializadas, sobre temas relativos às transexualidades e travestilidades, houve um fundamental esforço de imersão oculta em plataformas on-line ${ }^{1}$ para que fossem colhidos os comentários de leitores e leitoras de material jornalístico publicado no Portal Globo.com. Esse trabalho imersivo revelou intensas disputas em torno das questões de gênero e sexualidade e como estas vieram mobilizando opiniões inflamadas nas redes de comunicação on-line.

Acompanhar os comentários e postagens nas mídias digitais selecionadas nos colocou frente a um campo discursivo de ação (ALVAREZ, 2014) eivado por afetos. Para a autora:

Os campos discursivos de ação são muito mais do que meros aglomerados de organizações voltadas para uma determinada problemática; eles abarcam uma vasta gama de atoras/es individuais e coletivos e de lugares sociais, culturais e políticos. Os setores mais política e culturalmente visíveis desses campos, e os pontos nodais que os articulam, variam ao longo do tempo. Em diferentes momentos, distinta/os atoras/es ou vertentes ganha maior ou menor visibilidade política e cultural, e maior ou menor acesso ao microfone público e aos recursos

\footnotetext{
1 Na imersão oculta em plataforma on-line o/a pesquisador/a atua como lurker, um/a observador/a silencioso/a (BRAGA, 2016; AMARAL, 2010), isso quer dizer ele/a acompanha as relações sociais estabelecidas no ambiente digital sem interagir com os/as observados/as. É como se o/a estudioso/a estivesse filmando a dinâmica digital e por de trás de sua câmera, aquele/a que filma no caso o/a pesquisador/a fosse invisível.
} 
materiais e culturais, às vezes conseguindo se estabelecer como hegemônicos. (ALVAREZ, 2014, p.18).

As mídias sociais digitais têm sido cada vez mais usadas como um parâmetro para mensurar esses (des)afetos. Entre esse leque de questões discutidas no on-line, a transexualidade ganhou nos últimos cinco anos, período em que demarcamos o levantamento, cada vez mais a arena digital.

Os levantamentos a partir de palavras-chave (transexualidade; transexual; mulher transexual; transexual masculino; identidade de gênero; estudo de gênero; feminino; masculino; machismo; ideologia de gênero; feminismo; Judith Butler; transgênero; transgeneridade; homofobia; misoginia; feminicídio; transfobia e pessoa não binária) incluíram os anos de 2000 a 2018, em buscas no Portal Globo.com, o qual surge justamente em 2000, ano de nosso ponto de partida. Porém, o tempo de imersão englobou os anos de 2015 a 2018. Observar como a transexualidade foi discutida na rede on-line nesse período nos levou a perceber consistentes paralelos que já sinalizavam para o recrudescimento conservador que o país experimenta de forma mais acentuada a partir de 2013, com as derivações à direita das chamadas Jornadas de Junho, seguido dos atos políticos pelo impeachment de Dilma Rousseff ocorrido em 2016, e que culminou na eleição de Jair Messias Bolsonaro, em novembro de 2018.

À medida que a pesquisa foi sendo desenvolvida, um dos dados levantados e obtidos pela imersão on-line despertou efetivamente a atenção do/da pesquisador/a: o meme da ideologia de gênero. Dessa forma, o presente artigo tem como objetivos discutir como os memes foram usados como uma ferramenta deslegitimadora das teorias de gênero, a partir do escárnio expresso por meios imagéticos e gráficos. Bem como, ensaiar aproximações com os termos negacionismo e pós-verdade cotejando-os com alguns comentários dentre os mais de 21 mil recolhidos por Vieira Junior $^{2}$ (2018) ao longo da pesquisa. Toma como hipótese que o voto em um candidato de extrema direita, como se passou no Brasil, buscou seus fundamentos menos no cenário de crise econômica que em uma pauta moral que conseguiu articular corrupção política com questões tão amplas como educação das crianças, sexualidade e direitos humanos.

Para a análise dos dados, construímos nossos argumentos em diálogo com os estudos de gênero em sua vertente pós-estruturalista, os estudos queer, flertando, ainda com aportes das ciências políticas.

O título da pesquisa da qual este artigo deriva, inspirou-se em diversos memes que passaram a ironizar fotos de parentes amorosos que incitavam manifestações

2 Tais postagens e comentários são oriundos de um conjunto de textualidades digitais do Portal Globo.com e dos grupos do Facebook Transgente e do Hetero/Orgulho, sendo que este último teve o seu nome original camuflado por razões éticas. 
digitais afetuosas a crianças da família. As fotos eram seguidas das perguntas "quantas curtidas merece esse principezinho?" ou "quantas curtidas merece essa princesinha?". Esse tipo de postagem foi tido por algumas pessoas como piegas e assim passou a ser utilizada de maneira jocosa. Serviu também para incitar o olhar e convocar a reflexão sobre corpos historicamente alijados do campo da ontologia. A tese em questão inspirou-se nessa espécie de trocadilho digital em seu título: Quantas curtidas merece essa trans? Ali, não se pretendeu ironizar as pessoas transexuais e/ou travestis, mas jogar com a pergunta, remetendo às redes sociais digitais, suscitando (de)afetos e convocando leitoras e leitores a interagir, mesmo que indiretamente, com o texto, ao mesmo tempo que se remete quem lê ao ambiente das redes sociais digitais.

\section{O meme da ideologia}

Em brincadeiras pelas redes sociais, alguns usuários defendem que depois do pau-brasil, da cana de açúcar, do ouro e do café, o grande produto exportação do Brasil são os memes. Encontrados em diversas manifestações nas redes, esses podem ser vistos inicialmente sob a perspectiva do humor, sendo rapidamente difundidos (viralizados) (FALCÃO, 2017, p.132).

O meme foi anteriormente adotado como um conceito vindo da sociobiologia, antes de cair nas graças das redes sociais e posteriormente ser definido como todo viral que se propaga pela rede web. Enfim, tudo aquilo que se espalha (se repete) pela internet em frases, fotos, vídeos, entre outros, adotando linguagens verbovisuais ${ }^{3}$. "O meme agora é visto não somente como um conceito científico de base evolucionista, mas também como a nomeação de um modo recorrente de interrelação entre sujeitos, textos/enunciados e práticas sociais, ou seja, como um gênero discursivo" (FERREIRA \& VASCONCELOS, 2019 p.45).

Ao longo da imersão on-line o meme apareceu como estratégia discursiva para ridicularizar as questões relacionadas às identidades de gênero, acionando-se figuras de retórica reducionista e simplificadora de teorias de gênero, nomeada por seus detratores como ideologia, conforme se pode acompanhar na Figura 1.

\footnotetext{
3 Análogo à ideia de gene (informações genéticas) o biólogo Richard Dawkins na obra O Gene Egoísta, de 1976 reduziu o termo grego mimesis (imitação) à meme (informações culturais). E foi nesse estreitamento entre a cultura e a natureza que pela primeira vez o termo meme apareceu.
} 
Figura 1: Exemplos de meme da ideologia de gênero.

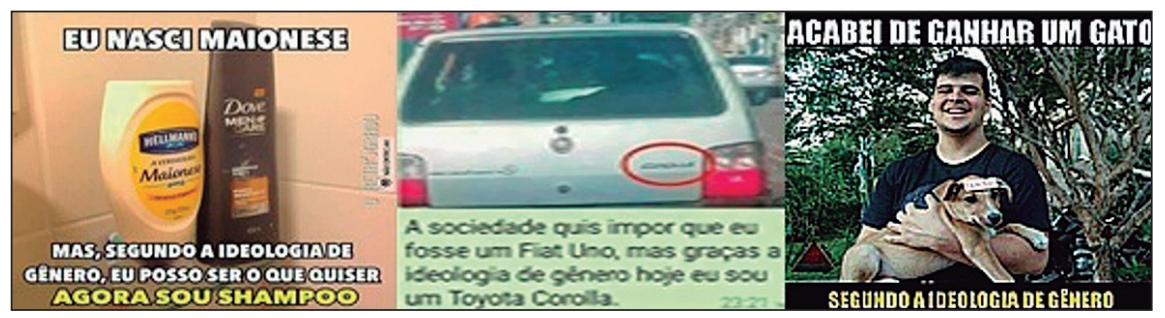

Fontes: https://witter.com/conexaopolitica/status/875477816472719361;

https://br.ifunny.co/picture/a-sociedade-quis-impor-que-eu-fosse-um-fiat-uno-g2QcThDs6.

Nos memes apresentados na Figura 1, as coisas se fetichizam, pois falam por si e agenciam uma suposta capacidade de se transformarem em algo diferente daquilo que seus rótulos e marcas anunciam. No meme que fecha a imagem, um homem declara que pelo imperativo de sua vontade seu cachorro seria um gato. Em todos os casos o que está insinuado é que o desejo de transexuais e/ou travestis em serem reconhecidas/dos a partir do gênero social e não do sexo genital, seria algo tão bizarro e risível quanto o voluntarismo dos objetos e do dono do animal. Ou seja, nada tem de racional ou defensável, pois pretende manipular a realidade a partir de percepções fantasiosas de si.

Observa-se, nos exemplos de imagens que compõem a Figura 1, que grande parte do poder do meme é imagético. Isso quer dizer que, as informações, principalmente quando usadas por meio de imagens, facilitam o entendimento daquilo que é transmitido, atuando de forma mais efetiva sobre os assuntos na vida social das pessoas. Outro item poderoso do meme é o humor. O humor é um instrumento de comunicação construído e voltado para a interação social, ou nas palavras de Ludwig Wittgenstein "o humor não é um estado de espírito, mas uma visão de mundo" (apud SALIBA, 2002, p.15).

A falácia da comparação entre voluntarismo individual e teorias fundamentadas em estudos desenvolvidos por diferentes campos de conhecimento ${ }^{4}$, é apagada pelo efeito humorístico que o meme pretende provocar. Ao atribuir o caráter ideológico ao Outro o discurso anti-gênero assume por meio do humor o locus moral de superioridade.

Qualquer pessoa que ri de outra acredita, nesse momento, que é superior a ela ao examiná-la e sente vontade de rir, e o riso, é sobretudo, a expressão de contentamento que inspira essa superioridade real ou imaginada. É possível rir

\footnotetext{
4 O conceito de gênero tem origem nas ciências biológicas e Psis (Psicologia, Psicanálise e Psiquiatria) sendo nos anos de 1980, apropriado pelos estudos feministas (FAUSTO-STERLING, 2001), os quais são multidisciplinares.
} 
de si mesmo $[. .$.$] o eu descobre o ridículo em qualquer uma das regiões inferiores$ do seu ser separa-se daquilo que ri, distingue-se dele e usufrui intimamente uma sagacidade que o eleva em sua própria estima (LAMENNAIS apud MINOIS, 2003, p.499).

O meme como "texto sucinto de cunho humorístico e de caráter verbo-visual que, mobilizando um remix cultural" (FERREIRA; VASCONCELOS, 2019 p.45) tem forte apelo comunicativo e, a partir das possibilidades das mídias digitais contemporâneas, pode ser facilmente replicado, armazenado e mesmo modificado uma vez que ele é composto a partir de um processo de "bricolagem", cujo "objetivo não reside na coerência entre os elementos, ou nas partes "juntadas", mas no objetivo final" (FALCÃO, 2017, p.170). No caso aqui analisado, ele apresenta-se para denunciar a dimensão ideológica e insidiosa da teoria de gênero tratada, então, com base no sintagma ideologia de gênero.

Em entrevista, Rogério Junqueira (LOWENKRON; MORA, 2017) explica que:

"Ideologia de gênero" é uma invenção católica que emergiu sob os desígnios do Conselho Pontifício para a Família, da Congregação para a Doutrina da Fé, entre meados da década de 1990 e no início dos 2000. Trata-se de um sintagma urdido no âmbito da formulação de uma retórica reacionária antifeminista, sintonizada com o pensamento e o catecismo de Karol Wojtyla. A matriz dessa retórica é católica - mais precisamente, neofundamentalista católica, contrária inclusive a disposições do Concílio Vaticano II. (LOWENKRON; MORA, 2017, n.p.).

O sintagma ideologia de gênero teve sua popularização na América Latina pelas vias do discurso leigo como o de Jorge Scala, advogado argentino. Scala publicou em 2010 o livro intitulado La ideología del género - O el género como herramienta de poder $^{5}$, por meio do qual reage às recentes conquistas de direitos sexuais e reprodutivos reverberando o que foi chamado de manipulação linguística de "'lobbies gays', feministas, que juntamente com defensores do multiculturalismo e do politicamente correto, extremistas ambientalistas, neomarxistas e outros pósmodernos, garantiriam a hegemonia daquela 'ideologia"' em ambientes de debates transnacionais em agências da Organização das Nações Unidas (ONU), por exemplo (JUNQUEIRA, 2017, p.224).

O irônico desta nomeação é que o próprio argumento de seus adeptos é tão ideológico quanto o que eles criticam. Argumentam que os debates sobre gênero e sexualidade, sobretudo, se levados no âmbito da educação formal, comprometeriam

5 Lançado no Brasil em 2011, com o título de Ideologia de Gênero: neototalitarismo e morte da família. 
a formação de famílias heterossexuais e procriativas, pois a diluição de papéis claros entre masculino e feminino corromperia a infância e, mais, colocaria em xeque a própria integridade social, a partir da alteração das pautas morais, desembocando mesmo na destruição da sociedade (MISKOLCI; CAMPANA, 2017).

Ainda que os verdadeiros ideólogos de gênero insistam em dizer que se trata de temas privados, conseguiram, como mostra Fernando Balieiro (2018), acionar o pânico moral em torno das transformações do presente, ativando a defesa das crianças como mote salvacionista. Balieiro (2018, n.p.) analisa que com esse argumento de proteção das crianças, "conseguiram barrar iniciativas de combate à homofobia nas escolas, impedir o uso do termo gênero nos planos educacionais e até impedir ou cercear mostras artísticas com o tema das sexualidades diversas". Teme-se não só que estruturas hierárquicas de gênero sejam abaladas, mas que com isso, a própria heterossexualidade, como sinônimo de ordem social, seja desafiada.

Em um olhar retrospectivo, quando voltamos aos comentários e postagens, encontramos um campo semântico no qual discursos misóginos, demonização dos avanços relativos à direitos sexuais e igualdade de gênero, perseguição às ciências humanas, anti-intelectualismo, expressos no enaltecimento da opinião versus argumentos sustentados por pesquisas, já indicavam que estava sendo gestada uma política de ressentimentos contra as agendas de direitos políticos estendidas a segmentos sociais historicamente alijados do campo dos direitos. O sintagma ideologia de gênero passou, então, a condensar uma vasta pauta moral que volta sua ira para as questões identitárias.

Os inimigos da nação tornavam-se aqueles e aquelas que supostamente poluem o corpo da nação: feministas, lgbtistas, comunistas, professores de esquerda, homossexuais, travestis, transexuais entre outros/as. Firmava-se a ideia de que havia pessoas e grupos que não mereceriam ascender ao status de cidadão e cidadã e que ao fazerem tornaram-se parasitárias, drenando não só recursos escassos do Estado, mas infeccionando com seus comportamentos o corpo social. Nas palavras de Achile Mbembe (2017a), referindo-se aos inimigos fantasmáticos acionados, mesmo em contextos democráticos, a fim de demonizar o Outro mais espectral que real.

Esses inimigos com os quais nenhum entendimento é possível ou desejável, aparecem em geral sob os traços de caricaturas, clichés e estereótipos. Caricaturas, clichés e estereótipos lhes concedem uma presença figural, essa forma de presença que, por sua vez, só faz confirmar o tipo de ameaça (ontológica) com a qual eles nos assombram (MBEMBE, 2017a, p.76). 
É Mbembe (2017a) ainda, que propõe que a instalação do medo é um elemento central nesse ambiente de inimizades. De fato, ele cunha o conceito de sociedade de inimizade para descrever o clima de desgaste das democracias contemporâneas, vampirizadas pelo neoliberalismo que precarizou o trabalho, exacerbou a competição, inflou a meritocracia e terceirizou os custos da ruína que ele promoveu às políticas inclusivas.

Ressituando o debate ao campo dos mais de 21 mil comentários recolhidos ao longo da pesquisa foi possível acompanhar "a configuração de uma gramática moral que consegue reduzir os medos e as desesperanças de pessoas comuns a uma tirania do óbvio", da verdade como escolha pessoal, do ignorante empoderado (DESLANDES, 2019, p.2-4). Em um momento que é mundial e, como destaca Daniel Kahneman, ganhador do prêmio Nobel de Economia: "quando as pessoas acreditam que uma conclusão é verdadeira, também ficam muito propensas a acreditar nos argumentos que parecem sustentá-la, mesmo que esses não sejam confiáveis". "Temos de nos fazer confiáveis, por isso não podemos estar nem caladas nem confinadas." (apud DESLANDES, 2019, p.2-4).

Nas redes de comunicação pesquisadas, sobretudo em meios aos comentários do Portal Globo.com, as críticas às políticas que ampliavam direitos às minorias políticas como transexuais e travestis foram associadas a uma espécie de capricho de alguns ilustrados que, tranquilos em seus privilégios, se esforçariam para colocar em prática o ditado popular "fazer cortesia com o chapéu alheio", uma vez que não teriam nada de material a perder, angariando desonestamente bens simbólicos como prestígio, enquanto pessoas honestas estariam sendo preteridas. Essas arbitrariedades teriam transposto os limites do aceitável, quando autoridades passaram a defender e legislar a partir desses parâmetros de inclusão e, mais grave, segundo alguns argumentos: usando o dinheiro público para atender interesses dos "maus-cidadãos", como no comentário reproduzido a seguir: "ridículo tanta gente morrendo nos hospitais públicos por falta de condições e remédios e até de médicos, e a juíza decide dá privilégio para um trans-homo ... inacreditável ... ele não corre risco de morte, dá para esperar!" - comentário na matéria "Justiça manda Estado fazer cirurgia de mudança de sexo em paciente" (GLOBO, 2016a, n.p.).

O termo trans-homo transcrito como no original, no comentário, para se referir a homens trans, pessoas que foram assignadas como mulheres ao nascer, mas ao longo de suas vidas se veem em conflito com as normas de gênero que prescrevem comportamentos, indumentária e usos específicos do corpo para homens e mulheres, buscando viver e serem identificados não pelas noções de senso comum

\footnotetext{
6 Rodrigo Borba (2019, n.p. tradução nossa) mostra por meio de RuthWodak que "a instanciação do medo é um elemento central da ação política dos anti-ativistas de gênero e o novo tipo de populismo de direita que endossam no Brasil e em outros lugares (...) uma POLÍTICA DO MEDO (Ênfase no original). O ódio como Mbembe (2017a) descreve se fundamenta na criação de inimigos.
} 
de feminilidade, mas como pessoas que se identificam com as masculinidades. Simone Ávila (2014) utiliza o conceito de transhomens

[...] por se tratar da uma tradução aproximada de transhomem, utilizado pela teórica queer Marie-Hélène Bourcier (2008); porque a palavra é um substantivo, algo que denomina os sujeitos, não um adjetivo, que os qualifica; e, por fim, para fugir de binarismos que ficariam implícitos na adjetivação homens trans/mulheres trans. (ÁVILA, 2014, p.32).

No comentário recortado por nós a forma como o termo foi grafado sugere mais uma associação da transexualidade com a orientação (homo)sexual do que com a experiência de gênero.

A locução "mau-cidadão" está sendo acionada aqui para se contrapor à “cidadãos de bem", expressão que passou a ganhar força política, no contexto do processo de impeachment da presidenta Dilma Rousseff (2015-2016). Ainda que seja bastante vaga como definição de um perfil político e/ou sociológico, mostrou sua eficiência retórica para traçar fronteiras morais entre "Nós" e "Eles". Constituída pelo contraste, o "cidadão de bem" reivindica para si retidão moral a partir da defesa da família como categoria genérica; pendor patriótico, associando-se ao verdeamarelo da bandeira nacional e rechaçando o vermelho como alienígena, associado ao comunismo como ideologia invasora e perigosa à ordem e à paz. Enfim, tudo que poderia soar como ameaça aos valores nacionalistas e heterossexistas compõe o "cidadão de bem", identidade que mal disfarça sua vocação racista e classista.

\section{O negacionismo dos estudos de gênero}

Nesse projeto ainda difuso, mas já com ares globais, negacionismo e falsificasionismo históricos são elementos presentes nos discursos ascendentes anti-humanistas, antifeministas, antidemocráticos, antipopulares e antiliberais (BALLESTRIN, 2018, p.157).

Como foi verificado ao longo da pesquisa, a temática gênero foi, e ainda é, uma das mais discutidas nesses últimos anos nas redes sociais. Porém, sua abordagem apareceu na pesquisa em questão, mais como ideologia do que como teoria. Keila Deslandes (2019, p.1-4) avalia que a onda conservadora que engolfou o país atinge de forma sensível "tanto no campo da Saúde quanto no da Educação". Para ela, "está em pauta o acirramento de uma agenda anti-igualitária sustentada por movimentos contrários às conquistas sociais e jurídicas de grupos historicamente subalternizados, cujos efeitos aprofundariam também as desigualdades de classe e étnico-raciais". 
Quando travestis e transexuais conquistam direitos, como obter o nome social, aquele pelo qual deseja ser reconhecido/a por estar de acordo com seu gênero, ou quando passam a ter acesso a tratamento e cirurgia de redesignação sexual por meio do Sistema Único de Saúde (SUS), entre outras conquistas que tornam suas vidas mais habitáveis, as reações recolhidas em nossa pesquisa, entre os comentários de matérias, se voltam também contra o governo que atende essas reivindicações:

Esse Brasil é um LIXO!!!!!!!!!!!! privilégios privilégios privilégios... transexualismo não é explicado pela ciência, nem essa invencionice de "identidade de gênero" e "orientação sexual". Não se apoia em nada, nao se justifica em nada. Redirecionar verba de problemas REAIS como cancer, cirurgias cardíacas e manutenção de hospitais para alimentar o FETICHE. (GLOBO, 2013, n.p., destaque nosso).

A inversão de valores na sociedade denigre o ser humano. Se amanhã você se sentir um rinoceronte! Você implanta um chifre nas narinas, ou vai a um psiquiatra?! Homens Capados é a melhor definição... falta de ter o q fazer... o governo gastando com o "luxo" para algumas pessoas, sendo que para outras coisas, é melhor deixar morrer... ptz. (GLOBO, 2012, n.p., destaque nosso).

Vamos nos ater aos comentários partindo dos trechos que destacamos. Comecemos pela negação das pesquisas científicas sobre transexualidade. $\mathrm{O}$ "transexualismo" ao contrário do que pensa o comentarista tem sido largamente explorado pela ciência pelo menos desde último terço do século XIX ao primeiro do século XX (LEITE JÚNIOR, 2011). Mas podemos adiantar a linha da história da transexualidade e do gênero para a década de 1960, quando, a partir da ideia de transexual verdadeiro, Harry Benjamin (1966) vai desenvolver por meio de escalas uma separação entre a figura da transexual e da travesti, a primeira associada a um problema de gênero no qual a cirurgia seria o bálsamo para o sofrimento de conflito entre a identidade de gênero e o corpo biológico e a segunda relacionada a um problema social, o fetichismo que para sua solução seria recomendável evitar parceiros sexuais (LEITE JÚNIOR, 2011).

Em 1972, os sexólogos John Money e Anke Ehrhardt popularizaram a ideia de que sexo e gênero são categorias separadas. Sexo, diziam, se refere aos atributos físicos e é anatômica e fisiologicamente determinado. Viam o gênero como uma transformação psicológica do eu - a convicção interior de que se é homem ou mulher (identidade de gênero) e as expressões comportamentais dessa convicção (FAUSTO-STELLING, 2001, p.15). 
Os estudos feministas, em suas diversas vertentes vão se apropriar do conceito de gênero transformando-o em categoria analítica (SCOTT, 1990; PISCITELLI, 2002) e teóricas e teóricos dos estudos queer vão mostrar que o binário heterossexualidade/homossexualidade organiza sociedades de matriz ocidental, naturalizando hierarquias e criando margens simbólicas onde aquelas e aqueles que escapam à norma heterossexual são alocados.

Falando a partir das margens, os teóricos queer buscam não só romper com o binarismo (...) ou questionar noções clássicas de sujeito, de identidade, de agência, que têm permeado o debate das Ciências Sociais e dos estudos feministas, mas também conferir um certo contorno ontológico àqueles que tem sido sistematicamente destituídos do privilégio da ontologia. Como discute Butler, "a matriz cultural por intermédio da qual a identidade de gênero se torna inteligível exige que certos tipos de 'identidade' não possam 'existir'”. (PELÚCIO, 2009, p.47).

Estas proposições sofisticadas foram mais distorcidas que simplificadas e, quando Judith Butler veio pela segunda vez ao Brasil, em 2017, ofereceu um corpo ao pânico moral que veio sendo orquestrado pelo menos desde 2011, quando há o reconhecimento legal das uniões entre pessoas do mesmo sexo no Brasil e Dilma Rousseff, que assumia seu segundo mandato, tomava como uma das primeiras medidas o veto ao "kit anti-homofobia", material didático cujo foco era a promoção de uma educação inclusiva com base no respeito à diversidade de gênero e sexual. A decisão da Dilma foi uma resposta acanhada à pressão de parlamentares ligados às igrejas católicas e evangélicas que afirmavam ser o material obsceno e sexualizador. À frente dessa campanha difamatória esteve Jair Bolsonaro, até então um obscuro deputado federal.

Foi assim que, em 2017, Judith Butler se tornaria alvo de gritos como "queimem a bruxa", proferidos por manifestantes contrários aquilo que tomaram como sendo as ideias de Butler: incentivo à pedofilia, conversão de crianças em homossexuais e o anulamento de normas que regulam sexo e gênero, como se isso fosse de fato possível em termos antropológicos e sociológicos. Durante a campanha eleitoral de 2018, Jair Bolsonaro reavivaria essa discussão tornando o "kit antihomofobia" em uma das mais potentes fake news de sua bem-sucedida máquina digital de produção de verdades.

Em grande parte dos comentários a opinião pessoal ocupou o lugar de expressão da verdade, secundarizando ou mesmo desqualificando o conhecimento científico sobre o tema, sobretudo se este conhecimento vem do campo das Humanidades. "A minha opinião" se torna mais importante que os argumentos de um especialista no assunto discutido no on-line. 
O economista Thomas Palley (2019, p.718), revendo e discutindo a história da ciência recorda-nos que: "Si una teoría representa uma amenaza suficiente para el statu quo, podrá ocurrir que no se le presten oídos o incluso que se busque decididamente suprimirla, y es posible que al actuar de ese modo se invoque el nombre de la ciência"'. E mais à frente, no mesmo artigo, ele cita o psicólogo social Leon Festiger:

Supongamos que un individuo cree en algo con todo su corazón... Supongamos que se le presentan evidencias inequívocas e innegables de que su creencia es infundada; ¿qué habrá de ocurrir? Con frecuencia el individuo no solamente se quedará imperturbable sino que estará aún más convencido que antes de que sus creencias se fundan en la verdad. Es más, incluso exhibirá un nuevo fervor al acometer la labor de convencer a la gente de lo acertado de su visión y buscar que se sume a su causa. (FESTIGER apud PALLEY, 2019, p. 736) ${ }^{8}$.

Ainda que o contexto que Palley (2019) aciona não seja aquele que abordamos aqui, estabelecemos as conexões com o pânico moral que relacionou crise econômica, criminalização da política institucional e corrupção moral (MISKOLCI; PEREIRA, 2019). Vale destacar que os comentários e as postagens negacionistas com as quais nos deparamos ao longo da pesquisa foram além de menções sobre gênero, fazem parte do seu repertório desde a negação do Holocausto, do aquecimento global até o formato elipsoide da Terra, que vulgarmente é chamada de redonda.

Em suma, a ideologia de gênero tornou-se o olho de um furacão que movimentou uma complexa rede de significados, categorias, marcadores, operadores políticos e forças (KALIL, 2018, p.4). A autora traz um conjunto desses elementos (temas) a partir de uma etnografia realizada entre os que estavam presentes nas manifestações contra a presença da filósofa Judith Butler em palestra no Sesc Pompéia, em São Paulo. Tal como Isabela Oliveira Kalil (2918), percebeu durante a realização de sua pesquisa pela internet, o autor e a autora deste artigo também perceberam como a categoria ideologia de gênero mobilizava um conjunto de temas que deveriam ser combatidos como transexualidade, feminismo, LGBT, comunismo, socialismo, travesti, homossexuais, bissexuais, pessoa não binária, partidos de

\footnotetext{
7 "Se uma teoria representa uma ameaça suficiente para o status quo, poderá ocorrer que não lhe deem ouvidos ou inclusive que se busque decididamente suprimi-la, e é possível que ao atuar desse modo se invoque o nome da ciência". Thomas Palley (2019, p.718, tradução nossa).

8 Suponhamos que um indivíduo crê em algo com todo seu coração...Suponhamos que the apresentem evidências inequívocas e inegáveis de que sua crença é infundada; O que ocorrerá? Com frequência o indivíduo não somente permanecerá imperturbável como estará ainda mais convencido do que antes de que suas crenças se fundam na verdade. E mais, exibirá um novo fervor empreendendo a tarefa de convencer as pessoas da sabedoria de sua visão, buscando que se associem à sua causa. ((FESTIGER apud PALLEY, 2019, p.736, tradução nossa).
} 
esquerda, indígenas, pluralidade de pensamento, diversidade cultural, laicidade, cultura, ciências humanas, intelectuais, ser humano, política, direitos humanos, cidadania, religiões afro, ateus, movimento trabalhadores rurais sem terra, aborto seguro, sexualidade, artes, sexo, desigualdade social, meio ambiente, imigrante, Mercosul, Organizações Nações Unidas (ONU), latino americano, nordestino, muçulmano, pesquisa científica, aspectos sociológicos, dados históricos, filosofia.

\section{Direitos trans versus "tudo isso que tá aí"}

Os discursos de ódio passaram a ser ostentados à luz do dia, as ações criminosas se tornaram banais e os assassinos do passado e do presente ganharam muitos defensores públicos, prontos para destruir os inimigos, como verificamos no período de campanha eleitoral: travesti assassinada por homens gritando o nome de Bolsonaro; algumas torcidas de futebol gritando "Bolsonaro vai matar viado", entre outras formas de violência. Essas atitudes revelam a expectativa de colocar em prática um desejo velado de destruição da população de lésbicas; gays; bissexuais; transexuais e transgêneros; e intersexuais (LGBTI+). Sem nenhum pudor, eles e elas se sentem no direito de agredir e até matar pessoas pelo simples fato de não estarem de acordo com as normas heterossexuais (ANDRADE, 2019, p.2-4).

"Tudo isso que tá aí", termo tão vago quanto abrangente, guarda na sua amplitude aversões que vão da recusa ao Partido dos Trabalhadores (PT) ao medo do fim da família e da promoção da homossexualidade nas escolas (KALIL, 2018). Assim, a ideologia de gênero se tornou um grande espantalho que enfeixa com sua envergadura frágil na estrutura, mas potente simbolicamente, sentidos que passaram a identificar por derivação a esquerda política com corrupção moral e favorecimento a segmentos populacionais que não mereceriam habitar a nação. Se a pessoa é a favor da identidade de gênero, ela é feminista. Sendo feminista é militante LGBT e aceita a transexualidade e a homossexualidade. É, portanto, comunista, o que implica em ser a favor da distribuição de renda, dos médicos cubanos, ateísta, no limite satanista. Adjetivações que se desdobram em teias aparentemente desconexas, mas que compõem, de fato, uma trama social costurada pelas linhas do temor da violação de valores tidos como intocáveis (heterossexualidade, sexualidade das crianças, família em modelo canônico, papéis de gênero, questões raciais) somada à orquestrada criminalização da política formal como sendo um campo de corrupção e arrematada pelo temor à crescente violência urbana. Nesse cenário, ser a favor de se discutir esses temas e/ou ampliar o campo dos direitos para segmentos historicamente subalternizados em nossa sociedade, é colocá-los em risco. 
Entre as postagens de seu blog, a socióloga e professora Berenice Bento (2016, n.p.) vê o estatuto da família, a escola e a proibição da teoria sobre gênero e sexualidade nas escolas, chamada distorcidamente e algumas vezes equivocadamente de ideologia de gênero, como ações de uma "elite política moral que se expressa politicamente via as bancadas BBB (Bíblia, boi, bala)" por um país/reino de Deus sem "lixo humano", pois não somente essa elite, mas toda a sociedade, família e até mesmo Deus se sentem ameaçados pelos movimentos feministas, LGBT, comunistas e os de direitos humanos. Enfim, uma vida (heteronormativa) que se sente ameaçada e desejosa de "limpeza social" mesmo que se viva "a heterossexualidade obrigatória em pleno funcionamento" social (BENTO, 2016, n.p.). A mínima possibilidade oposta ao modelo heteronormativo impositivo é vista como uma terrível ameaça que deve ser combatida.

Para Jacques Sémelin (2009) a necessidade de purificação social faz ver a morte como necessária, desejável e justificável, e dessa maneira a sociedade não enxergará como um assassinato a morte de algumas pessoas porque se estará fazendo, para fins terapêuticos, uma limpeza que prima pela saúde social. Esse anseio social é elemento discursivo em comentários postados em portais de notícias combatendo a transexualidade e para isso se valem, por vezes, de distorções que são colocadas como verdade. Para tal, utiliza-se fake news (notícias falsas) ${ }^{9}$ que associam a transexualidade a tudo que a sociedade moralmente acredita ser ameaçador e mau para o corpo social sacramentalizado.

É um processo biopolítico que por valorizar a vida (de alguns grupos) mata aqueles grupos que são considerados ameaçadores e por esta razão acabam se tornando bode expiatório, culpados por todo mal que assola a sociedade (AGAMBEN, 2002). Assim, as pessoas trans também se tornam e acabam sendo incluídas no pacote das perseguições na categoria de elimináveis, como os homossexuais, os pobres, os negros, os imigrantes, os intelectuais, os artistas e os comunistas. ${ }^{10} \mathrm{Um}$ dos enunciados, entre os comentários, que chama atenção é o de que "a transexualidade é coisa de esquerdista, isso é ideologia de gênero"; utilizando-se o argumento de que "a transexualidade não é de Deus e é contra a vontade de Deus." Vamos a alguns comentários recolhidos.

\footnotetext{
9 Com o número de notícias falsas, cada vez maior, o "G1 lança Fato ou Fake, novo serviço de checagem de conteúdos suspeitos" (GLOBO, 2018c, n.p.) no dia 30 de julho de 2018.

${ }^{10}$ A gramática moral reinante aproximou grupos de interesse laicos como o Movimento Brasil Livre (MBL) e o Escola sem Partido, de religiosos (católicos e evangélicos, neopentecostais ou não), de maneira que sua aliança reforçou a tendência de atribuir problemas sociais concretos a inimigos imaginários, que podem ser comunistas, gays, feministas, pessoas trans. Esse tipo de prática política se alicerça em uma visão de mundo dividida entre os que representariam "o Bem" e os que representariam "o Mal". Da política para a moral, grupos de interesse passaram a demonizar pleitos de direitos humanos por parte de mulheres, homossexuais, pessoas trans, travestis, intersex, entre outrxs, concatenando-os no fantasma que batizaram de "ideologia de gênero".
} 
Mulher é XX --- Homem é XY. Fora isso é engenharia social marxista para destruir a família...Marx engendrou a estrutura da ideologia de gênero visando destruir a família, com intuito de inviabilizar a cultura da posse de propriedade, que era na cabeça dele, a razão de todo mal. Ele acreditava q a família era o alicerce da ideia de propriedade, logo quis destruir a família como ela é. (GLOBO, 2018a, n.p., destaques nossos).

Esse negócio de gênero quem inventou foi os marxistas politicamente correto, fica na base do discurso. Para saber se e macho ou fêmea e só olhar os cromossomos xy homem xx mulher, no ser humano e assim. o resto são palavras que o vento leva e a pessoa fala o que quer, mas não o que é. (GLOBO, 2016b, n.p., destaques nossos).

Imundícia! Podridão! Agora qualquer folgado vai poder 'virar mulher' quando completar 30 anos de trabalho pra se aposentar antes. Esse STF PORCO indicado pelo condenado nove dedos de esquerda deveria ser todo fuzilado na praça dos 3 poderes. (GLOBO, 2018b, n.p., destaques nossos).

Olhem na primeira foto, essxs são os típicos eleitores do PSOL e PT, l.i.x.os! (GLOBO, 2016c, n.p., destaques nossos).

O progressismo esquerdista vai acabar com a civilização ocidental!!!!! os valores, princípios, moralidade e tudo mais que conhecemos... Deixa teu filho em casa assistindo rede globo o dia inteiro pra ver se ele não vira um mongolóide esquerdopata comunista feminista transgênero. (GLOBO, 2017, n.p., destaques nossos) ${ }^{11}$.

Os comentários, os grupos, as páginas digitais e as figuras difundidas on-line, regularmente partem do princípio de que a transexualidade sendo um desvio deve ser corrigido e não algo aceito, como as políticas dos governos mais à esquerda tenderam fazer. Frequentemente, devido à efervescência das discussões sobre gênero, a transexualidade acaba sendo alvo de demonização/monstrificação. Monstrificar e coisificar (SÉMELIN, 2009), autoriza o escárnio, a perseguição e, no limite, a eliminação daquele que ameaça a ordem. É ser lançado/lançada para fora do campo da ontologia, do possível e do dizível. Quem somos quando somos indizíveis?

Inspirada em Julia Kristeva, a teórica queer Judith Butler (2000) propõe pensar alguns corpos/experiências como enredadas por processos de abjeção. Quem são os abjetos? Ela contorna a questão, pois, elencar pessoas ou grupos a partir dessa chave seria assumir uma coerência constituinte da própria ideia de abjeto, que de fato o conceito não comporta. "Suas proposições sobre a existência de corpos abjetos

\footnotetext{
11 Na reportagem "Quem Sou Eu?: Conheça crianças transgêneros na estreia da nova série" (GLOBO, 2017 , n.p.) a palavra "Deus" aparece 28 vezes em 16 comentários e a palavra "comunismo" 10 vezes em 10 comentários.
} 
são francamente contraditórias. Mas, diz ela, são propositalmente contraditórias: colocadas como fórmulas performativas, são feitas para impor ou invocar essa existência "impossível"' (PRINS \& MEIJER, 2002, p.156). As aspas marcam que essa "impossibilidade" não é intrínseca à condição orgânica do corpo abjeto, mas deriva das normas e convenções sociais que tornam certas vidas inabitáveis. A vida daqueles e daquelas que não mereceriam gozar de direitos, os "maus cidadãos" que ameaçam uma suposta ordem de uma experiência comunitária percebida como homogênea e ordenada. A corrupção da ordem viria dos excessos de direitos concedidos a quem não os merecia: os "maus cidadãos".

É preciso levar a sério o conteúdo dos comentários recolhidos no decorrer da pesquisa, nas teias discursivas digitais. Antes de desmerecê-los e desqualificá-los, propomos ser mais proveitoso interrogar-nos sobre o que faz deles verdades? De onde vem sua potência argumentativa? O que sustenta percepções como a afirmação de que a transexualidade não é uma questão de identidade de gênero, que não tem bases científicas e que se trata de uma "sem vergonhice"? Ou, por que assistir a uma determinada rede de televisão torna crianças e adolescentes transexuais e homossexuais? E se isso acontecesse, por que seria ruim?

Ao afirmarem que Karl Marx inventou a ideologia de gênero muitos/as comentaristas não estão, provavelmente, percebendo-se como produtores/as e replicadores/as de inverdades, mas estão lutando para preservar um regime de verdades.

\section{O uso de fake news para uma pós-verdade de gênero}

Em um mundo de irracionalidade e pós-verdade - nome elegante para as mentiras organizadas -, prover dados certos e argumentações racionais é um perigo. As redes sociais paradoxalmente democratizaram o acesso a mentiras e falácias que - não espontaneamente - circulam em grande velocidade e escala. $\mathrm{O}$ ataque que não se dá desde um lugar romanticamente plebeu, anti-intelectual e anticlassista (ainda que se assente em tendências históricas de reação crítica diante do elitismo universitário) - vai além do plano intelectual, teórico ou de estilos de comunicação e se dirige diretamente a indivíduos que são perseguidos, encontramse sob ameaça inclusive física, têm seus recursos cortados e são atacados com técnicas orquestradas de escárnio público. (PECHENY, 2019, p.3-4).

Apesar de ser colocada como um novo conceito, a questão da pós-verdade não surgiu com as redes sociais on-line; já era discutida e problematizada por Nietzsche (1979 [1887]) que admitia que não há fatos, apenas versões e por Foucault (2006) que a chama de falsa verdade, construção de verdade ou discurso de verdade. Há 
ainda, que se considerar o recente fenômeno que ficou conhecido como fake news, a produção de matérias em formato jornalístico que, de fato, não estão baseadas em dados concretos ou em realidades empíricas verificáveis. É importante fazer a ressalva de que os memes e as fake news não são inverdades, são discursos e, portanto, contemplam efeitos de verdades. Observa-se que nem sempre quando as pessoas postam e defendem ideias estarão acreditando integralmente nelas, ainda que devamos considerar que na maior parte das vezes devem acreditar. Isto não quer dizer que essas pessoas possuam uma moralidade estoica. Talvez seja importante que outras pesquisas explorem esses discursos cotejando-os com o modo como as pessoas que os proferem agem no seu dia-a-dia. Talvez nos deparemos com pastores que exploram financeiramente os fiéis; heterossexuais que consumem pornografia gay e com políticos que não hesitam em usar recursos públicos para fins pessoais. De forma que, se isso de fato acontece, o moralismo torna-se uma estratégia biopolítica para governar e, em última instância, eliminar corpos ingovernáveis.

É interessante, ainda, pensar que a potência de propagação dessas pósverdades, "nome elegante para as mentiras organizadas", como definiu Mário Pecheny $(2019$, p.3) na epígrafe que abre esta seção, está no fato de haver uma parte da população que encontra nas fake news suas ideias e valores sistematizados, organizados e expostos em formato crível. Muitas vezes, o entusiasmo é tal, que o conteúdo completo sequer é lido, atendo-se apenas à manchete, gerando replicações rápidas, confiando-se, mais na força da mensagem que na fonte emissora. Confiase no emissor, assim o conteúdo tende a ser igualmente percebido como confiável, como no grupo Hetero/Orgulho (nome modificado para preservar a privacidade do mesmo). Sentindo-se ameaçados pelo que foi chamado em vários fóruns on-line e off-line como "ditadura gay", os membros do grupo não só se valem de memes para enaltecer a heterossexualidade (ainda que muitos destes sejam misóginos, como aparece na Figura 2), como replicam notícias e artigos que possam respaldá-los na defesa de seus privilégios.

Figura 2: Memes nos quais há naturalização das habilidades dos gêneros e nas duas últimas imagens objetificando as mulheres.

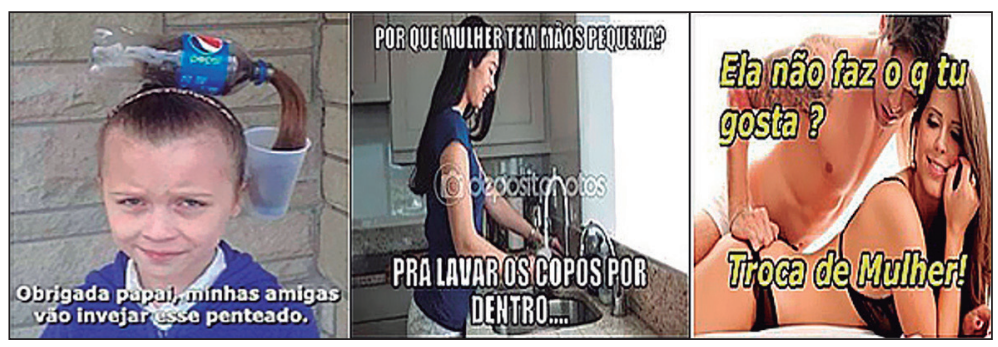

Fonte: Grupo Hetero/Orgulho (Facebook) 
Ideias que respaldam valores do Grupo são, muitas vezes, editadas e selecionadas para amplificar os fatos como, por exemplo, um vídeo intitulado Ditadura gay postado na página Marco Feliciano ${ }^{12}$ e compartilhado no grupo Hetero/Orgulho que pede para os pais exigirem que as escolas não ensinem ideologia de gênero. Ao longo do vídeo, vários outros fatos são distorcidos, entre eles de que o nazismo é um partido de esquerda (e não de extrema direita), e mesmo que o regime tenha perseguido e matado homossexuais (fato que é ocultado) fornece fundamentos para a "ditadura gay" que é percebida atualmente como cada vez mais insidiosa. Segundo o vídeo, tal como o nazismo, a ditadura LGBT obriga todas as pessoas aceitarem a homossexualidade e tudo aquilo se associa a ela como, por exemplo, o comunismo. Uma imposição gay que segundo a página Marco Feliciano usa da força e da violência cometida por travestis mesmo que, na realidade, elas sejam as mais vulneráveis à violência e morte como revela a pesquisa Transgender Europe (2014). Porém, dados que colocam as travestis como vítimas e não como algozes não são publicados em suas postagens. "Em um mundo já fortemente polarizado, o "efeito rede" potencializa a intolerância, a impaciência e o ódio. Escutamos só o que queremos e o que reforça os nossos preconceitos" (GENESINI, 2018, p.54-55).

As fake news estão arraigadas no sistema de crenças anti-intelectualista. Por isso existe, constantemente, nas postagens de grupos como do Hetero/Orgulho, desprezo às ciências humanas personificadas nas figuras do/a sociólogo/a, do/a filosofo/a, do/a historiador/a. São figuras vistas como ameaçadoras e a serem combatidas para que o ato de matar não seja visto como assassinato; torturar não seja considerado violação de direitos humanos; espancar mulheres até a morte, não seja feminicídio; agredir homossexuais, não consista em homofobia; linchar travestis e transexuais, não seja definido como transfobia e muitas vezes nem sequer seja um crime.

O enaltecimento da opinião versus argumentos, sustentados por pesquisas indicaram, a partir da análise desses Grupos digitais, que vinha sendo gestada uma política de ressentimentos. Ester Solano (2018) explica que a emergência de um pensamento de extrema-direita no Brasil se deu a partir do uso estratégico de discursos de ódio os quais procuravam associar políticas inclusivas à corrupção política e moral. Jair Bolsonaro e seus acólitos souberam associar insatisfações coletivas relativas à crise econômica, que se agravou durante o governo de Dilma Rousseff, à criminalização da política institucional, orquestrada pelas grandes empresas de comunicação brasileiras e a falta de segurança pública ao

\footnotetext{
12 É o conteúdo gráfico digital oficial de Marco Antônio Feliciano, deputado federal brasileiro do Partido Social Cristão (PSC), que é um pastor da Catedral do Avivamento, uma igreja neopentecostal ligada à Assembleia de Deus. Tal página possui uma atualização diária de postagens em sua maioria de cunho religioso, bélico e moral em que tem como o tema de conteúdo e adesão nas redes sociais \#ANossaFamíliaMereceRespeito.
} 
campo progressista. A forma agressiva e tida como autêntica de Jair Bolsonaro se posicionar, somada à sua incitação ao armamento da população como recurso para combater a criminalidade e garantir a segurança pessoal, encontrou grande apoio. $\mathrm{O}$ ódio foi associado à coragem de dizer a verdade, o que de forma maniqueísta alocava a mentira e a corrupção no campo da esquerda política e se transformava em uma espécie de política espontânea do ódio. Espontânea porque faz crer que a indignação é individual e que os indivíduos isolados se encontram, por exemplo, on-line enxergando-se uns nos comentários dos outros, legitimando em boa medida sentimentos que foram, isto sim, orquestrados como políticas de governo ou ações pensadas por grupos organizados, tais como parlamentares da bancada BBB (bala, boi, Bíblia). O ódio como política (SOLANO, 2018) faz com que as pessoas acreditem ou queiram acreditar, mesmo quando os fatos propalados não são comprováveis em um exame mais cuidadoso.

\section{Considerações finais ou quem ri por último...}

Neste contexto, os empreendedores políticos de maior sucesso serão aqueles que falarem de maneira convincente aos perdedores, aos homens e mulheres destruídos pela globalização e pelas suas identidades arruinadas. A política se converterá na luta de rua e a razão não importará. Nem os fatos. A política voltará a ser um assunto de sobrevivência brutal em um ambiente ultracompetitivo. (MBEMBE, 2017b, n.p.).

A imersão on-line revelou que, principalmente, a partir de 2016 (eleição de Donald Trump nos Estados Unidos e o processo de impeachment de Dilma Rousseff no Brasil) as fake news ou hoax (que são os boatos) ganharam força de verdade na internet (pós-verdade). Para o pesquisador Felipe de Oliveira, em entrevista a Vitor Necchi (2017), as novas sociabilidades na web, entre elas, particularmente, as redes sociais digitais, permitiram a criação de um terreno fértil para a propagação da (des)informação de modo que uma enxurrada de informações produzidas pelas redes digitais atuam como função de imprensa, revelando dessa maneira como a desprofissionalização da produção de conteúdo noticioso abriu uma clareira na qual a intolerância grassou. Na sua expressão mais raivosa a intolerância e o ressentimento deram luz aos discursos de ódio. Estes não costumam lidar com dados resultantes de pesquisas, aliás, costumam mesmo desqualificar essas fontes, sejam elas quantitativas ou qualitativas, para poder sustentar os discursos que hierarquizam vidas a partir de critérios morais assentados no "bom uso" do gênero.

A negação obsessiva às demandas de pessoas trans para o acesso à saúde, educação e ao trabalho aparecem nos comentários que estabelecem hierarquias de 
urgências, pautadas em parâmetros morais que decidem quem merece ser atendido, nessa contenda por bens escassos e aqueles/as que podem esperar para obterem recursos, mesmo que isso implique em morte literal ou simbólica. Numa espécie de apropriação brutalista do biopoder como sintetiza Michel Foucault (1999): "fazer viver, deixar morrer", comentaristas vão além, propondo mesmo necropolíticas. "Brasil acima de tudo e Deus acima de todos", slogan da campanha presidencial de Jair Bolsonaro não só reatualizou o mote nazista (Alemanha acima de tudo/ "Deutschland über alles"), como foi capaz de sintetizar a lógica autoritária de uma ideia de nação pura regida por forças sagradas e não por relações de poder, que são sempre sociais. A ideia de que havia pessoas e grupos que não mereceriam ascender ao status de cidadão/ã e que ao o fazerem tornaram-se parasitárias, drenando não só recursos escassos do Estado, mas infeccionando com seus comportamentos o corpo social, já estava nos comentários que vínhamos lendo, mas com a ascensão de Jair Bolsonaro como "mito", o campo discursivo de ação se adensou. Bolsonaro passou a encarnar "o desejo (...) pela eliminação sistemática daqueles corpos que poluem a pureza de uma nação imaginada" (BENTO, 2018, n.p.). Nas palavras da socióloga Berenice Bento inspirada em Michel Foucault (biopolítica) e Achile Mbembe (necropolítica), trata-se da promoção de uma necrobiopolítica. Bento define necrobiopoder como "um conjunto de técnicas de promoção da vida e da morte a partir de atributos que qualificam e distribuem os corpos em uma hierarquia que retira deles a possibilidade de reconhecimento como humano e que, portanto, devem ser eliminados e outros que devem viver" (BENTO, 2018, n.p.).

Os memes, as fake news e pós-verdades com as quais nos deparamos ao longo da pesquisa não revelaram um discurso propriamente novo em torno das sexualidades não-normativas. Ao contrário, apareceram como ferramentas discursivas capazes de reavivar crenças e medos que acreditávamos estar superando a partir do alargamento do campo dos direitos humanos no Brasil, bem como pelo crescimento dos estudos de gênero e sexualidade. Deparamo-nos com "negacionismo e falsificasionismo históricos [...], elementos presentes nos discursos ascendentes anti-humanistas, antifeministas, antidemocráticos, antipopulares e antiliberais" próprios de um momento global "pós-democrático" (BALLESTRIN, 2018, p.157).

Finalmente, o negacionismo que antes encontrávamos nos comentários de cidadãos/ãs comuns no Portal Globo.com ou nos Grupos do Facebook passaram a ser reproduzidos, após a posse de Jair Bolsonaro, em discursos oficiais do próprio presidente e/ou de ministros/as de seu governo. O staff político parece ter sido escolhido para ocupar as pastas justamente pela negação daquilo que elas deveriam defender e administrar como, por exemplo, promoções de políticas que protejam o meio ambiente, promovam a educação e assegurem os direitos humanos. Entre todos os memes políticos com os quais nos deparamos talvez seja esse entre todos o mais viral, no sentido lato do termo: uma toxina com capacidade de se autorreplicar. 
Memes, fake news e pós-verdade ou como a teoria de gênero vira uma "ideologia perigosa"

Burroughs (2013) conceitua os memes políticos como parte de uma ecologia da mídia e uma esfera pública agonística na internet. Já Lawrance (2015), se referindo à organização fundamentalista BokoHaram como um meme, descreve o conceito como uma 'ferramenta de referência cultural' capaz de exprimir medos e ansiedades através da repetição de imagens mentais. [...] esses conteúdos [...] participam de um debate normativo sobre como o mundo deveria ser e qual a melhor forma de alcançar este objetivo (CHAGAS, 2018, p.9).

Em tempos de movimento antivacina, precisamos urgentemente, buscar saídas políticas capazes de desenvolver em nós uma memória imunológica, contra os fascismos de ocasião.

\title{
MEMES, FAKE NEWS AND POST-TRUTH OR HOW GENDER THEORY BECOMES A "DANGEROUS IDEOLOGY"
}

\begin{abstract}
This article is based on and also the result of the thesis named "How many 'likes' do you think this 'trans' deserves" The receptivity of transsexuality in digital media-carried out from the year 2015 to 2018, from hidden online immersion in the journalistic portal Globo.com and in two Facebook groups focused on gender issues. The immersive work revealed intense disputes and inflamed opinions around gender issues. The "meme of gender ideology" was a fact in the research which attracted attention, such as the "negationism" and "post-truth" material relating above all to moral issues, ironizing and/or rejecting behavioral changes attributed to government corrupting policies and possibly encouraging a reversal of values. The memes were used as a kind of "war weapons" against gender theories which converted into "dangerous ideology". In order to analyze the research findings, theoretical tools from the studies of gender in their post-structuralist form, the queer studies and also contributions from the political sciences were used in this article.
\end{abstract}

KEYWORDS: Gender theory. Gender ideology. Memes. Post-Truth. Negationism.

\section{MEMES, NOTICIAS FALSAS Y POST-VERDAD O CÓMO LA TEORÍA DE GÉNERO SE CONVIERTE EN UNA "IDEOLOGÍA PELIGROSA"}

RESUMEN: Este artículo se basa en la tesis denominada “¿Cuántos 'me gusta' crees que este trans merece?”, realizada durante los años 2015 y 2018, a partir de la inmersión en línea oculta en el portal periodístico Globo.com y en dos grupos de Facebook centrados en cuestiones de género. El trabajo de inmersión reveló 
intensas disputas y opiniones inflamadas en torno a cuestiones de género. El "meme de la ideología de género" fue un hecho que llamó la atención en la investigación, como también el "negacionismo" y el "post-verdad" material que tocaba sobre todo cuestiones morales, burlándose y/o rechazando cambios de comportamiento, atribuidos a políticas gubernamentales que corrompen la moral y que alentarían la inversión de valores. Los memes fueron usados como una especie de "arma de guerra" contra las teorías de género, convertidas en "ideología peligrosa". Para el análisis de los resultados de la investigación, utilizamos las herramientas teóricas de los estudios de género en su aspecto postestructuralista, de los estudios queer, también haciendo uso de las contribuciones de las ciencias políticas.

PALABRAS CLAVE: Teoría de género. Ideología de género. Memes. Post-Verdad. Negacionismo.

\section{REFERÊNCIAS}

AGAMBEN, Giorgio. Homo sacer: o poder soberano e a vida nua. Belo Horizonte: Editora da UFMG, 2002.

ALVAREZ, Sonia E. Para além da sociedade civil: reflexões sobre o campo feminista. Cadernos Pagu (43), janeiro-junho, 2014. Disponível em: http://www.scielo.br/scielo. php?script=sci_arttext\&pid=S0104-83332014000200013. Acesso em: 10 dez. 2014.

AMARAL, Adriana da Rosa. Etnografia na pesquisa em cibercultura. Limites e insuficiências metodológicas. Revista USP, v. 1, p. 122-135, 2010. Disponível em: http://www.revistas. usp.br/revusp/article/view/13818. Acesso em: 19 dez. 2017.

ANDRADE, Luma Nogueira de. LGBTI+ no Brasil: o golpe de 2016 e a facada de 2018. Interface - Comunicação, Saúde, Educação, 23, e190156. Epub June 13, 2019. Disponível em: https://dx.doi.org/10.1590/interface.190156. Acesso em: 19 nov. 2019.

ÁVILA, Simone N. FTM, transhomem, homem trans, trans, homem: A emergência de transmasculinidades no Brasil contemporâneo. Tese - Doutorado em Ciências Humanas, da Universidade Federal de Santa Catarina. 2014. Disponível em: https://repositorio.ufsc.br/ xmlui/handle/123456789/129050. Acesso em: 10 out. 2014.

BALIEIRO, Fernando Figueiredo. Não se meta com meus filhos: a construção do pânico moral da criança sob ameaça. Cadernos Pagu, e185306, 2018. Disponível em: http://www. scielo.br/scielo.php?pid=S0104-83332018000200406\&script=sci_abstract\&tlng=pt. Acesso em: 30 out. 2018. 
BALlESTRIN, Luciana. O Debate Pós-democrático no Século XXI. Revista SulAmericana de Ciência Política, v. 4, p. 149-164, 2018. Disponível em: https://periodicos. ufpel.edu.br/ojs2/index.php/rsulacp/article/view/14824. Acesso em: 08 out. 2018.

BENJAMIN, Harry. El fenómeno transexual. Sevilha, 1966.

BENTO, Berenice. Necrobiopoder: Quem pode habitar o Estado-nação? Cadernos Pagu, n.53, e185305. Epub June 11, 2018. Disponível em: http://www.scielo.br/scielo. php?script=sci_arttext\&pid=S0104-83332018000200405. Acesso em: 18 out. 2018.

BENTO, Berenice. Heteroterrorismo e o lixo humano. BLOG, 2016. Disponível em: http:// berenicebento.blogspot.com.br/2016/04/heteroterrorismoe-o-lixo-humano.html. Acesso em: 02 dez. 2016.

BORBA, Rodrigo. Gendered politics of enmity: language ideologies and social polarization in Brazil. Gender and Language, vol. 13, n. 4, 2019.

BOURCIER, Marie-Hélène. Technotesto: biopolitiques des masculinités tr(s)ans hommes. Cahiers du Genre, N. 45, 2008. Disponível em: https://www.cairn.info/revue-cahiers-dugenre-2008-2-page-59.htm. Acesso em: 10 out. 2018.

BRAGA, Adriana Andrade. Técnica etnográfica aplicada à comunicação online: uma discussão metodológica. UNIrevista. UNISINOS, v. 1, p. 1-11, 2006. Disponível em: http:// www.unirevista.unisinos.br/_pdf/UNIrev_Braga.PDF. Acesso em: 10 fev. 2018.

BUTLER, Judith. Problemas de gênero: feminismo e subversão da identidade. Rio de Janeiro: Civilização brasileira, 2003.

BUTLER, Judith. Corpos que pesam: sobre os limites discursivos do "sexo". In: LOURO, Guacira Lopes (org.): O corpo educado. Pedagogias da sexualidade. Belo Horizonte: Autêntica, p.153-172, 2000.

CHAGAS, Viktor. A febre dos memes de política. REVISTA FAMECOS, v. 25, p.27025, 2018. Disponível em: http://revistaseletronicas.pucrs.br/ojs/index.php/revistafamecos/article/ view/27025. Acesso em: 10 ago. 2019.

DAWKINS, Richard. O gene egoísta. São Paulo: Companhia das Letras, 1976.

DESLANDES, Keila. Sobre disputas anti-igualitárias e políticas públicas: mais argumentos para o debate. Interface, vol.23. Botucatu, Epub June 13, 2019. Disponível em: http://www. scielo.br/scielo.php?pid=S1414-32832019000100402\&script=sci_arttext. Acesso em: 29 ago. 2019.

FALCÃO, Thiago H. Memes, textões e problematizações: sociabilidade e política a partir de uma comunidade de LGBT universitários no Facebook. Dissertação - Mestrado em 
Antropologia Social. Universidade Estadual de Campinas, 2017. Disponível em: http:// repositorio.unicamp.br/jspui/handle/REPOSIP/322133. Acesso em: 29 ago. 2019.

FAUSTO-STERLING, Anne. Dualismo em duelo. Cadernos Pagu, n. 17-18, p.9-79, 2001. Disponível em: http://www.scielo.br/pdf/cpa/n17-18/n17a02. Acesso em: 29 ago. 2019.

FERREIRA, Dina M. M; VACONCELOS, Marco A. Discurso de memes: (Des)memetizando ideologia antifeminista. Bakhtiniana, São Paulo, 14 (2): 44-61, Abril/Junho, 2019. Disponível em: http://www.scielo.br/pdf/bak/v14n2/2176-4573-bak-14-02-0044.pdf. Acesso em: 29 ago. 2019.

FOUCAULT, Michel. A Ordem do Discurso. São Paulo: Loyola, 2006.

FOUCAULT, Michel. Em defesa da sociedade. São Paulo: Martins Fontes, 1999.

GENESINI, S. A pós-verdade é uma notícia falsa. Revista USP, n. 116, p.45-58, 29 maio 2018. Disponível em: http://www.revistas.usp.br/revusp/article/view/146577. Acesso em: 09 mai. 2020.

JUNQUEIRA, Rogério Diniz. "Ideologia de Gênero": a gênese de uma categoria política reacionária - ou: a promoção dos direitos humanos tornou-se uma "ameaça à família natural"? In: RIBEIRO, Paula R.; MAGALHÃES, Joanalira C. (Org.). Debates contemporâneos sobre educação para a sexualidade. Rio Grande: Ed. Furg, 2017. Disponível em: http:// www.educadores.diaadia.pr.gov.br/arquivos/File/pdf/livro_debates_contemporaneos_ educacao_sexualidade.pdf. Acesso em: 20 ago. 2018.

KALIL, Isabela Oliveira. Notas sobre 'Os Fins da Democracia': etnografar protestos, manifestações e enfrentamentos políticos. Revista do núcleo de antropologia urbana da USP. Ponto Urbe 22, 2018. Disponível em: https://journals.openedition.org/pontourbe/3933. Acesso em: 20 ago. 2018.

LEITE JÚNIOR, Jorge. "Nossos Corpos Também Mudam": sexo, gênero e a invenção das categorias "travesti" e "transexual" no discurso científico. São Paulo: Annablume, 2011.

LOWENKRON, Laura; MORA, Cláudia. A gênese de uma categoria. CLAM+10. 2017. Disponível em: http://clam.org.br/destaque/conteudo.asp?cod=12704. Acesso em: 20 ago. 2019.

MBEMBE, Achille. Políticas da Inimizade. Lisboa: Antígona, 2017a.

MBEMBE, Achille. A era do humanismo está terminando. IHU - Revista do Instituto Humanitas Unisinos, 24 de janeiro 2017b. Disponível em: http://www.ihu.unisinos.br/78noticias/564255-achille-mbembe-a-era-dohumanismo-esta-terminand. Acesso em: 25 ago. 2019.

MINOIS, Georges. História do riso e do escárnio. São Paulo: Unesp, 2003. 
MISKOLCI, Richard; PEREIRA, Pedro P.G. Desigualdades mortais: a fabricação de vidas precárias no Brasil. Interface. Botucatu, 2019; 23: e190157. Disponível em: https://www. scielosp.org/article/icse/2019.v23/e190157/. Acesso em: 25 ago. 2019.

MISKOLCI, Richard; CAMPANA, Maximiliano. "Ideologia de gênero": notas para a genealogia de um pânico moral contemporâneo. Revista Sociedade e Estado - Volume 32, Número 3, Setembro/Dezembro 2017. Disponível em: http://www.scielo.br/pdf/se/ v32n3/0102-6992-se-32-03-725.pdf. Acesso em: 25 set. 2018.

NECCHI, Vitor. Jornalismo deve fazer mediação qualificada entre acontecimentos e a sociedade. IHU - Revista do Instituto Humanitas Unisinos. Edição 502, 10 Abril 2017. Disponível em: http://www.ihuonline.unisinos.br/media/pdf/IHUOnlineEdicao502.pdf. Acesso em: 25 set. 2018.

NIETZSCHE, Friedrich. (1887). Fragments posthumes. Automne 1885 - automne 1887. Oeuvres philosophiques complètes, XII. Paris: Galimard, 1887. Euvres philosophiques complètes XII Fragments posthumes (Automne 1885 - Automne 1887). Trad. de l'allemand par Julien Hervier. Collection (Euvres philosophiques complètes ( $\left.{ }^{\circ} 12\right)$, Gallimard. Parution: 09-11-1979.

PALLEY, Thomas I. Desigualdad y estancamiento por diseño de políticas: el negacionismo predominante y sus peligrosas consecuencias políticas. EI Trimestre Económico, vol. LXXXVI (3), núm. 343, julio-septiembre de 2019, p.717-739. Disponível em: http://www. revistas-conacyt.unam.mx/trimestre/index.php/te/article/view/876/1063. Acesso em: 25 ago. 2019.

PECHENY, Mario Martín. Restaurações conservadoras na Argentina e no Brasil: o íntimo e o público sob ataque. Interface - Comunicação, Saúde, Educação. Botucatu, v.23, e19005, jun. 2019. Disponível em: http://www.scielo.br/scielo.php?script=sci_arttext\&pid=S141432832019000100401\&lng=en\&nrm=iso. Acesso em: 25 ago. 2019.

PELÚCIO, Larissa. Amor em tempos de aplicativos: masculinidades heterossexuais e a negociações de afetos na nova economia do desejo. Tese (livre-docência). Universidade Estadual Paulista Júlio de Mesquita Filho, Faculdade de Arquitetura, Artes e Comunicação, 2017. Disponível em: http://hdl.handle.net/11449/154656. Acesso em: 09 mai. 2020.

PELÚCIO, Larissa. Abjeção e Desejo: uma etnografia travesti sobre o modelo preventivo de aids. 1. ed. São Paulo: Annablume-FAPESP, 2009.

PISCITELLI, Adriana. "Recriando a (categoria) mulher?” In: ALGRANTI, Leila (Org.). A prática feminista e o conceito de gênero. Campinas: IFCH-Unicamp, 2002. Disponível em: http://www.pagu.unicamp.br/sites/www.pagu.unicamp.br/files/Adriana01.pdf. Acesso em: 26 ago. 2019. 
PRINS, Baukje; MEIJER, Irene Costera. Como os corpos se tornam matéria: entrevista com Judith Butler. Revista Estudos Feministas, 10(1), p.155-167, 2002. Disponível em: https:// dx.doi.org/10.1590/S0104-026X2002000100009. Acesso em: 25 ago. 2019.

SALIBA, Elias Thomé. Raízes do riso. São Paulo: Cia das Letras, 2002.

SCALA, Jorge. La ideología de género: o el género como herramienta de poder. Madrid: Sekotia, 2010.

SCOTT, Joan. Gênero, uma categoria útil de análise histórica. Educação e Realidade, Porto Alegre, 16(2), jul/dez., p.5-22, 1990. Disponível em: http://www.direito.mppr.mp.br/ arquivos/File/SCOTTJoanGenero.pdf. Acesso em: 25 ago. 2019.

SÉMELIN, Jacques. Purificar e Destruir: Usos políticos dos massacres e dos genocídios. Rio de Janeiro: Difel, 2009.

SOLANO, Esther. O ódio como política: A reinvenção das direitas no Brasil. São Paulo, Boitempo, 2018.

TRANSGENDER EUROPE. Trans Murder Monitoring. 2014. Disponível em: https://tgeu. org/tag/trans-murder-monitoring/. Acesso em: 12 jun. 2020.

VIEIRA JUNIOR, Luiz Augusto Mugnai. “Quantas Curtidas Merece essa Trans?”: a Recepção da Transexualidade Nas Mídias Digitais. Tese - Doutorado em Ciências Sociais. Programa de Pós-Graduação em Ciências Sociais da Faculdade de Filosofia e Ciências da Universidade Estadual Paulista/UNESP - Campus Marília, 2018.

\section{Fontes jornalísticas}

GLOBO. 'Monstro, prostituta, bichinha': como a Justiça condenou a $1^{\mathrm{a}}$ cirurgia de mudança de sexo do Brasil e sentenciou médico à prisão. G1. Disponível em: https://g1.globo.com/ bemestar/noticia/monstro-prostituta-bichinha-como-a-justica-condenou-a-1a-cirurgia-demudanca-de-sexo-do-brasil-e-sentenciou-medico-a-prisao.ghtml. Acesso em: 28 mar. 2018a.

GLOBO. STF decide que transexuais e transgêneros poderão mudar registro civil sem necessidade de cirurgia. G1. Disponível em: https://g1.globo.com/politica/noticia/stf-decideque-transexual-podera-mudar-registro-civil-sem-necessidade-de-cirurgia.ghtml. Acesso em: 01 mar.2018b.

GLOBO. G1 lança Fato ou Fake, novo serviço de checagem de conteúdos suspeitos. G1. Disponível em: https:/g1.globo.com/fato-ou-fake/noticia/2018/07/30/g1-lanca-fato-ou-fakenovo-servico-de-checagem-de-conteudos-suspeitos.ghtml. Acesso em: 30 jul. 2018c. 
GLOBO. Quem Sou Eu? Conheça crianças transgêneros na estreia da nova série. G1. Disponível em: http://g1.globo.com/fantastico/noticia/2017/03/quem-sou-eu-conhecacriancas-transgeneros-na-estreia-da-nova-serie.html. Acesso em: 13 mar. 2017.

GLOBO. Justiça manda Estado fazer cirurgia de mudança de sexo em paciente. G1. Disponível em: http://g1.globo.com/sp/ribeirao-preto-franca/noticia/2016/11/justica-mandaestado-fazer-cirurgia-de-mudanca-de-sexo-em-paciente.html. Acesso em: 24 nov. $2016 \mathrm{a}$.

GLOBO. Policiais que não impediram agressão a travesti são afastados. G1. Disponível em: http:/g1.globo.com/pa/para/noticia/2016/10/policiais-que-nao-impediram-agressao-travestisao-afastados.html. Acesso em: 21 out. $2016 \mathrm{~b}$.

GLOBO. Torturei minha “"garotinha' durante anos”, diz mãe sobre aceitação de filho transgênero; relato viralizou. G1. Disponível em: http://g1.globo.com/bemestar/ noticia/2016/10/torturei-minha-garotinha-durante-anos-diz-mae-sobre-aceitacao-de-filhotransgenero-relato-viralizou.html. Acesso em: 10 out. 2016c.

GLOBO. Transexuais e travestis podem usar nome social no cartão do SUS em SP. G1. Disponível em: http:/g1.globo.com/sao-paulo/noticia/2013/03/transexuais-e-travestispodem-usar-nome-social-no-cartao-do-sus-em-sp.html. Acesso em: 15 mai. 2013.

GLOBO. Transexuais do DF esperam até seis anos por cirurgia para troca de sexo. G1. Disponível em: http://g1.globo.com/distrito-federal/noticia/2012/03/transexuais-do-dfesperam-ate-seis-anos-por-cirurgia-para-troca-de-sexo.html. Acesso em: 08 mar.2012.

Recebido em 16/03/2020.

Aprovado em 06/05/2020. 
